\title{
KONVERGENSI UPAH MINIMUM KABUPATEN/KOTA DI PULAU JAWA TAHUN 2014-2018:
}

Pendekatan Geographically Weighted Panel Regression

\author{
(REGIONAL MINIMUM WAGE \\ CONVERGENCE IN JAVA ISLAND 2014- \\ 2018: \\ Geographically Weighted Panel \\ Regression Approach)
}

\author{
Insan Riski Dwi Perdana ${ }^{1}$, Ernawati \\ Pasaribu ${ }^{2}$ \\ ${ }^{1}$ Politeknik Statistika STIS \\ ${ }^{2}$ Politeknik Statistika STIS
}

Jl. Otto Iskandardinata No. 64C, Bidara Cina, Jatinegara, Jakarta Timur 13330

E-mail: 16.9197@stis.ac.id

\begin{abstract}
ABSTRAK
Pulau Jawa merupakan pusat perekonomian di Indonesia dengan share terhadap PDB sebesar 59\% pada tahun 2018. Tingginya output yang dihasilkan tidak diimbangi dengan upah minimum yang ditetapkan. Terdapat beberapa daerah di Pulau Jawa yang menetapkan upah minimum dibawah rata-rata upah minimum nasional. Perusahaan akan berpindah menuju daerah dengan upah rendah untuk memperoleh tenaga kerja yang murah. Peningkatan UMK diperlukan untuk menjamin pekerja dapat memenuhi kebutuhan hidup secara layak. Pengingkatan upah secara terus menerus dapat memicu konvergensi antar daerah. Penelitian ini

\section{PENDAHULUAN}

Sebagian besar negara telah berhasil mencapai pertumbuhan ekonomi yang tinggi, akan tetapi ada yang belum berhasil memperbaiki taraf hidup sebagian besar penduduknya. Oleh karena itu tujuan utama pembangunan tidak hanya menciptakan pertumbuhan ekonomi yang tinggi tetapi juga penghapusan atau pengurangan kemiskinan, penanggulangan ketimpangan pendapatan, dan penyediaan lapangan pekerjaan. Di negara berkembang seperti Indonesia, perhatian utama dalam pembangunan terpecah antara pertumbuhan ekonomi dan distribusi pendapatan. Kedua hal tersebut penting untuk diwujudkan, namun sulit untuk diwujudkan secara bersama dikarenakan harus ada salah satu yang dikorbankan (Todaro, 2000).

Indonesia merupakan negara dengan jumlah penduduk terbesar ke-4 di dunia. Sumber daya manusia yang melimpah seharusnya dapat mendorong peningkatan produksi sehingga dapat 
meningkatkan pendapatan perkapita. Berdasarkan data BPS, pada tahun 2014 sampai tahun 2018 pertumbuhan PDB di Indonesia sebesar 4,88\% hingga 5,17\%. Akan tetapi pertumbuhan PDB Perkapita masih dibawah Pertumbuhan PDB sebesar 3,522\% sampai 3,93\%. Hal ini menunjukkan bahwa peningkatan produksi di Indonesia masih belum sepenuhnya dapat diikuti dengan tingkat kesejahteraan penduduknya.

Dalam proses produksi terdapat peran penting dari tenaga kerja. Upah yang diterima oleh pekerja dibayarkan menurut perjanjian kerja, kesepakatan, atau peraturan perundang-undangan. Terdapat perbedaan pandangan antara perusahaan dan pekerja mengenai upah yang ditetapkan. Bagi perusahaan, upah yang diberikan kepada pekerja merupakan biaya produksi yang mempengaruhi laba yang diperoleh. Akan tetapi, seringkali perusahaan enggan untuk menaikkan upah yang diberikan untuk menaikkan taraf hidup pekerja, terutama pekerja pada golongan bawah yang memperoleh upah paling sedikit.

Pemerintah sebagai pembuat kebijakan mempunyai peran untuk mengatasi masalah pengupahan di Indonesia dengan membuat aturan tentang upah minimum. Menurut Simanjuntak (2002) Pelaksanaan upah minimum bertujuan untuk memproteksi pekerja untuk mempertahankan agar nilai upah yang diterima tidak menurun dalam memenuhi kebutuhan hidup sehari-hari dan sebagai proteksi bagi perusahaan untuk mempertahankan produktivitas kerja.

Sejak diberlakukannya otonomi daerah, wewenang penetapan upah minimum menjadi kewajiban pemerintah daerah yang meliputi pemerintah provinsi hingga pemerintah kabupaten. Menurut Peraturan Menteri Tenaga Kerja dan Transmigrasi Nomor 7 Tahun 2013, upah minimum adalah upah bulanan terendah yang terdiri atas upah pokok termasuk tunjangan tetap yang ditetapkan oleh gubernur sebagai jaring pengaman. Upah minimum yang ditetapkan terdiri dari Upah Minimum Provinsi (UMP) dan Upah Minimum Kabupaten (UMK).

Meskipun upah minimum yang ditetapkan pemerintah mengalami kenaikan setiap tahun, masih banyak daerah di Pulau Jawa yang menetapkan upah minimum dibawah rata-rata upah minimum nasional. Selain itu, sebagian besar upah minimum yang ditetapkan di Pulau Jawa lebih rendah dibandingkan upah minimum yang ditetapkan pada daerah-daerah di luar Pulau Jawa. Masalah lain yang dihadapi adalah kesenjangan upah yang terjadi antar kabupaten/kota di Pulau Jawa.

Pembangunan yang dilakukan pemerintah bertujuan untuk meningkatkan kesejahteraan dan mengurangi ketimpangan yang terjadi. Berkurangnya ketimpangan dalam waktu yang lama dapat mengakibatkan konvergensi. Konvergensi diartikan sebagai kondisi dimana daerah miskin dapat tumbuh dengan cepat sehingga ketimpangan antar daerah semakin mengecil (Barro, 1992). Akan tetapi, konvergensi tidak hanya terjadi karena aktivitas ekonomi pada daerah itu sendiri tetapi juga karena adanya interaksi dengan daerah lain. Selain itu, pembangunan sarana perekonomian seringkali terjadi pada daerah di sekitar kota besar karena kemudahan akses dan infrastruktur yang sudah memadai. Keterkaitan spasial antar daerah tidak dapat diabaikan dalam memperhitungkan konvergensi. Selain itu, penetapan upah minimum oleh masing-masing kepala daerah menimbulkan keragaman antar daerah baik pada upah minimum yang ditetapkan maupun faktor yang dipertimbangkan sehingga sesuai dengan karakteristik masing-masing daerah. oleh karena itu, penelitian ini memperhitungkan aspek spasial yaitu keragaman spasial pada daerah yang diteliti.

Penelitian tentang konvergensi diawali oleh Barro dan Martin (1992) yang mengawali penelitian tentang konvergensi pendapatan. Penelitian mengenai konvergensi upah dilakukan oleh Moazzami (1997) melakukan penelitian tentang konvergensi upah antar daerah di Kanada menggunakan metode Error Correction Model (ECM). Mazza dan Villaverde (2006) menganalisis konvergensi teritorial di Spanyol dari perspektif upah riil untuk periode 1995-2001. Penelitian konvergensi dengan pendekatan GWR dilakukan oleh Eckey, Kosfeld, dan Turc (2005). Sedangkan konvergensi upah dengan pendekatan UMK di Pulau Kalimantan diteliti oleh Arishaldi (2018).

Penelitian ini secara umum bertujuan untuk mengidentifikasi konvergensi UMK di Pulau jawa dengan mempertimbangkan karakteristik yang dimiliki oleh masing-masing Kabupaten/Kota. Adapun tujuan khusus adalah: (1) Mengetahui gambaran umum UMK, Tingkat Kesempatan Kerja, Pendapatan Asli Daerah, dan PDRB di Pulau Jawa; (2) Mengetahui apakah terjadi konvergensi 
UMK di Pulau Jawa; (3) Menganalisis pengaruh Tingkat Kesempatan Kerja, Pendapatan Asli Daerah, dan PDRB terhadap pertumbuhan UMK di Pulau Jawa.

\section{METODE}

\section{Konvergensi}

Terdapat dua konsep konvergensi yaitu konvergensi beta $(\beta)$ dan konvergensi sigma $(\sigma)$. Menurut Baumol (1986), tanda negatif pada beta $(\beta)$ yaitu lag dari pendapatan berarti bahwa tingkat pertumbuhan pendapatan pada tahun $\mathrm{t}$ berkorelasi negatif dengan pendapatan pada periode awal. Dalam konvergensi beta terdapat konvergensi absolut dan konvergensi kondisional. Menurut (Barro, 1992) konvergensi absolut terjadi ketika daerah miskin tumbuh lebih cepat dari daerah kaya. Sedangkan konvergensi kondisional mengindikasikan bahwa selain pendapatan awal periode, terdapat variabel lain yang berpengaruh terhadap pertumbuhan pendapatan. Sedangkan Konvergensi sigma $(\sigma)$ mengukur tingkat dispersi tingkat pendapatan. Konvergensi dapat diukur dengan menggunakan ukuran dispersi dalam hal ini adalah koefisien variasi (Bernard dan Jones, 1996). Model konvergensi yang digunakan mengacu pada (Barro \& Sala-i-Martin, 2004) sebagai berikut.

$\ln \left(\frac{Y_{i, t}}{Y_{i, t-1}}\right)=\alpha+\beta \ln Y_{i, t-1}+u_{i t}$

Kecepatan konvergensi $(\lambda)$ dihitung dengan $\lambda=-\ln (1+\beta)$. Sedangkan waktu untuk menutup separuh kesenjangan (half-life) dihitung menggunakan $T=\frac{\ln 2}{\lambda}$.

\section{GWR-Panel}

Menurut Bruna dan Yu (2013), metode Geographically Weighted Panel Regression (GWRPanel) merupakan regresi lokal dengan pengulangan data pada titik wilayah untuk setiap pengamatan spasial. Dalam GWR-Panel diasumsikan bahwa runtutan waktu dari observasi pada sebuah lokasi geografis merupakan realisasi dari sebuah proses smooth spatiotemporal. Proses ini mengikuti distribusi observasi terdekat lebih berhubungan daripada observasi yang jauh (Yu, 2010). Dalam penelitian ini diasumsikan bahwa kondisi tiap unit saling berbeda sehingga menggunakan regresi panel dengan model FEM (Rahayu, 2017). Kombinasi antara persamaan GWR dan regresi panel FEM dengan within estimator adalah sebagai berikut.

$\ddot{y}_{i t}=\beta_{0}\left(u_{i t}, v_{i t}\right)+\sum_{k=1}^{p} \ddot{x}_{i t k} \beta_{k}\left(u_{i t}, v_{i t}\right)+\ddot{\varepsilon}_{i t}, i=1,2, \ldots, N, t=1,2, \ldots, T$.

\section{Metode Analisis}

Analisis inferensia yang digunakan dalam penelitian ini adalah analisis konvergensi yang terdiri dari konvergensi sigma dan konvergensi beta. Analisis konvergensi beta dilakukan dengan menganalisis konvergensi beta absolut dan beta kondisional. Dalam analisis konvergensi beta absolut hanya menggunakan lag UMK sebagai variabel independen. Sedangkan dalam analisis konvergensi beta kondisional memasukkan variabel kontrol yaitu PDRB, PAD, dan TKK. Analisis konvergensi beta kondisional dilakukan dengan metode Geographically Weighted Panel Regression (GWR-Panel).

Model yang digunakan dalam analisis konvergensi absolut mengacu pada penelitian Barro dan Sala-I Martin (1992), yaitu:

$\ln \frac{\widehat{U M K_{l, t}}}{U M K_{l, t-1}}=\alpha+\beta \ln U M K_{i, t-1}+u_{i, t}$ berikut.

Sedangkan model yang digunakan dalam analisis konvergensi kondisional adalah sebagai 
$\ln \frac{\widehat{U M K}_{i, t}}{U M K_{i, t-1}}=\alpha\left(u_{i t}, v_{i t}\right)+\beta_{0}\left(u_{i t}, v_{i t}\right) \ln U M K_{i, t-1}+\gamma_{1}\left(u_{i t}, v_{i t}\right) \ln P D R B_{i, t}+\gamma_{2}\left(u_{i t}, v_{i t}\right) \ln T K K_{i, t}+$ $\gamma_{3}\left(u_{i t}, v_{i t}\right) \ln P A D_{i t}+u_{i, t}$

Dimana:

$U M K_{i, t} \quad=$ UMK daerah i pada tahun ke-t

$U M K_{i, t-1}=$ UMK daerah i pada tahun sebelumnya $(\mathrm{t}-1)$

$P D R B_{i, t} \quad=$ PDRB daerah i pada tahun ke-t

$T K K_{i, t} \quad=$ Tingkat Kesempatan Kerja daerah i pada tahun ke-t

$P A D_{i t} \quad=$ Pendapatan Asli Daerah daerah i pada tahun ke-t

$\alpha, \beta, \gamma \quad=$ konstanta

$u_{i, t} \quad=$ error term

$\left(u_{i t}, v_{i t}\right) \quad=$ koordinat

\section{HASIL DAN PEMBAHASAN}

Sejak diberlakukannya otonomi daerah, penentuan upah minimum yang menjadi tanggung jawab pemerintah daerah. Kepala pemerintah mulai dari gubernur hingga bupati/walikota terlibat dalam penentuan upah minimum. Penetapan upah minimum didasarkan pada Kebutuhan Hidup Layak (KHL). Selain menetapkan Upah minimum Provinsi (UMP), gubernur juga menetapkan Upah Minimum Kabupaten (UMK) dengan memperhatikan rekomendasi dewan pengupahan provinsi dan rekomendasi dari bupati/walikota. Gubernur dapat menetapkan upah minimum lebih rendah, lebih tinggi, atau sama dengan nilai KHL. Hal ini menyebabkan perbedaan tingkat upah yang bervariasi pada setiap kabupaten/kota.

Pulau Jawa merupakan pusat perekonomian di Indonesia. PDRB yang dihasilkan di Pulau Jawa mencakup 59 \% dari PDRB total pada tahun 2018. Tingginya PDRB yang dihasilkan di Pulau Jawa tidak diikuti dengan indikator-indikator sosial seperti kemiskinan dan pengangguran yang angkanya masih cukup tinggi, yaitu masing-masing sebesar 8,32 \% dan 5,8 \%. Hal ini menunjukkan bahwa perkembangan ekonomi di Pulau Jawa belum menunjukkan kesejahteraan penduduknya. Dari sisi ekonomi, diperlukan indikator yang lebih mampu menggambarkan kesejahteraan penduduk, seperti upah minimum yang diberlakukan pada setiap daerah.

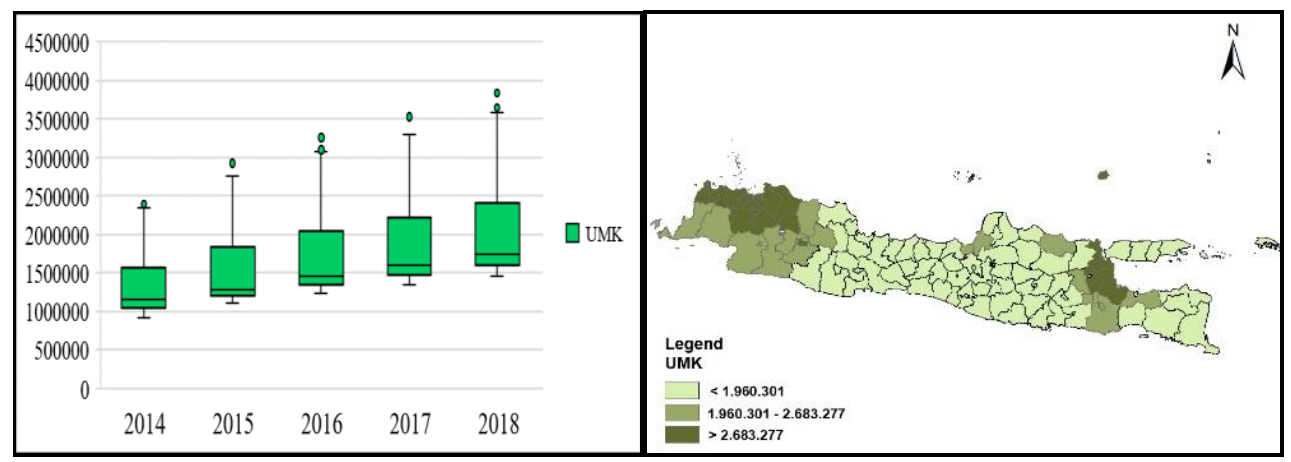

Gambar 1. Boxplot dan sebaran UMK di Pulau Jawa

Upah minimum kabupaten/kota di Pulau Jawa meningkat dari tahun 2014 hingga tahun 2018. Rata-rata UMK meningkat sebesar 54 persen dari Rp. 1.371 .324 pada tahun 2014 menjadi Rp. 2.119.894 pada tahun 2018. Dari gambar 1 dapat dilihat bahwa distribusi upah minimum cenderung miring ke kanan yang menunjukkan bahwa lebih banyak daerah dengan UMK di bawah rata-rata UMK di Pulau Jawa. Upah minimum paling tinggi di Pulau Jawa pada tahun 2018 adalah Kabupaten Karawang sebesar Rp. 3.919.291 sedangkan daerah dengan upah minimum paling rendah adalah Kabupaten Gunungkidul sebesar Rp. 1.454.200. Pertumbuhan UMK paling tinggi dari tahun 2014 hingga 2018 adalah Kota Semarang 19,4 sedangkan daerah dengan pertumbuhan 
UMK paling rendah adalah Kabupaten Salatiga sebesar 7,5\%. Dari gambar 1 dapat diketahui bahwa daerah dengan UMK yang tinggi mengumpul di sekitar pusat perekonomian seperti Jakarta dan Surabaya. Hal ini berbeda dengan daerah dengan UMK rendah yang berkelompok jauh dari pusat perekonomian.

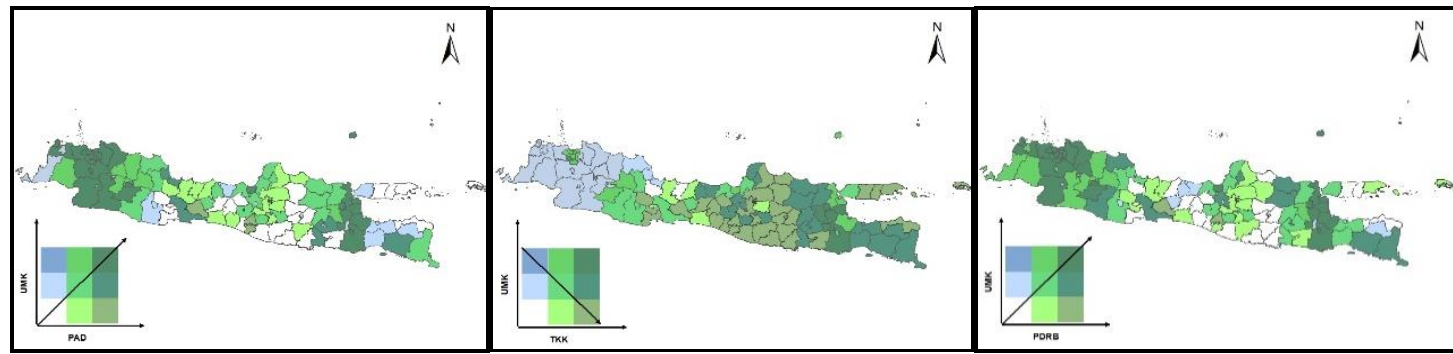

(i)

(ii)

(iii)

Gambar 2. (i) Keterkaitan PAD dengan UMK, (ii) ketertaitan TKK dengan UMK, (iii) keterkaitan PDRB dengan UMK

Rata-rata PAD pada setiap kabupaten/kota di Pulau Jawa mempunyai trend yang meningkat meskipun mengalami penurunan pada tahun 2018. Rata-rata PAD tahun 2018 sebesar 417,79 miliar sedangkan tahun 2018 meningkat menjadi 616,11 miliar rupiah. Rata-rata pertumbuhan PAD adalah 11 persen tiap tahun. PAD dan UMK dibagi kedalam tiga golongan, berdasarkan jenis pengelompokan dengan natural break. Terdapat indikasi adanya hubungan antara PAD dengan UMK dimana terlihat adanya pengelompokan daerah dengan PAD tinggi dengan UMK tinggi yaitu di DKI Jakarta, sebagian wilayah Provinsi Jawa Barat dan Jawa Timur. Sebaliknya, daerah dengan PAD rendah dengan UMK rendah mengelompok di sebagian wilayah di Provinsi Jawa Tengah dan Jawa Timur.

TKK di Pulau Jawa mengalami peningkatan dari tahun 2014 hingga tahun 2018. TKK tahun 2014 sebesar 93,54 persen naik menjadi 94,14 persen pada tahun 2018. Rata-rata kenaikan TKK tiap tahun adalah 0,16 persen. Terdapat indikasi adanya hubungan antara TKK dengan UMK dimana terlihat adanya pengelompokan daerah dengan TKK tinggi dengan UMK rendah yaitu di sebagian besar wilayah Provinsi Jawa Tengah, DI Yogyakarta, serta beberapa daerah di Provinsi Jawa Timur. Sebaliknya, daerah dengan TKK rendah dengan UMK tinggi mengelompok di sebagian wilayah di Provinsi Banten dan Jawa Barat.

Rata-rata PDRB di Pulau Jawa mengalami peningkatan dari tahun 2014 hingga tahun 2018. Rata-rata PDRB pada tahun 2014 sebesar 33,71 triliun rupiah dan pada tahun 2018 menjadi 42,11 triliun rupiah dengan pertumbuhan rata-rata tiap tahun sebesar 5,7 persen. Terdapat indikasi adanya hubungan antara PDRB dengan UMK dimana terlihat adanya pengelompokan daerah dengan PDRB tinggi dengan UMK tinggi yaitu di DKI Jakarta, sebagian wilayah Provinsi Jawa Barat dan Jawa Timur. Sebaliknya, daerah dengan PDRB rendah dengan UMK rendah mengelompok di sebagian wilayah di Provinsi Jawa Tengah, DI Yogyakarta dan beberapa daerah di Provinsi Jawa Timur.

\section{Analisis Konvergensi Sigma}

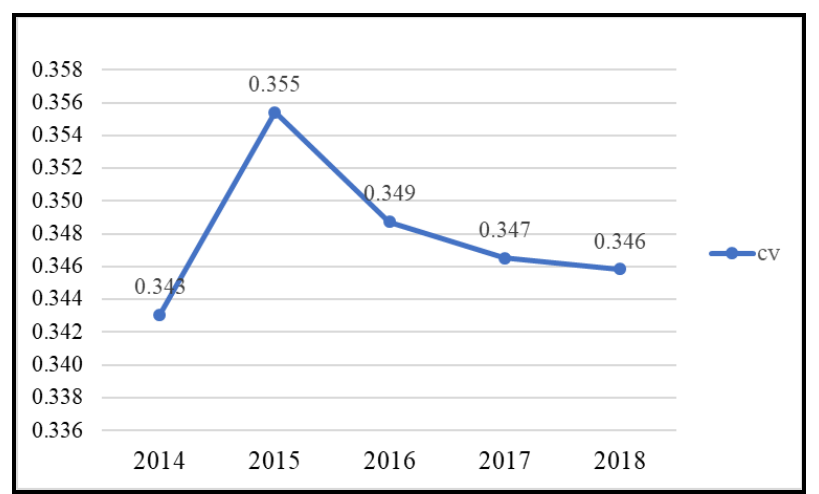


Gambar 3. Koefisien variasi UMK di Pulau Jawa tahun 2014-2018

Analisis konvergensi sigma pada sebaran nilai upah minimum kabupaten/kota menggunakan koefisien variasi. Konvergensi sigma terjadi ketika koefisien variasi mengalami penurunan trend dari tahun awal hingga tahun akhir. Berdasarkan gambar 3 nilai koefisien variasi UMK di Pulau Jawa tahun 2014 hingga 2018 berfluktuasi. Meskipun berfluktuasi, nilai koefisien variasi UMK mengalami trend yang menurun sejak tahun 2015. Kondisi ini menjelaskan terjadinya konvergensi sigma pada UMK di Pulau Jawa.

\section{Analisis Konvergensi Beta Absolut}

Dalam menganalisis konvergensi beta absolut pada Upah Minimum Kabupaten (UMK) dilakukan dengan regresi data panel pada masing-masing kabupaten/kota di Pulau Jawa pada periode 2014-2018. Variabel dependen yang digunakan adalah UMK tahun $t$ dan variabel independen adalah UMK pada tahun sebelumnya (UMK $\mathrm{t}_{\mathrm{t}-1}$ ). Metode estimasi yang tepat digunakan untuk fixed effect model adalah Feasible Generalized Least Square dengan cross-section weights dan Seemingly Unrelated Regression (SUR) karena tidak terpenuhinya asumsi homoskedastisitas dan nonautokorelasi.

Tabel 1. Konvergensi beta absolut UMK di Pulau Jawa.

\begin{tabular}{lllll}
\hline Variabel & Koefisien & Std Error & t-stat & P-value \\
\hline InUMKi,t-1 & $-0,1695$ & 0,0200 & $-8,4531$ & 0,0000 \\
Konstanta & 2,5274 & 0,2854 & 8,8572 & 0,0000 \\
& & & \\
$\lambda$ & 0,185 & & \\
Half-life & 3,73 & Ringkasan Statistik & \\
\hline \multicolumn{5}{r}{ R-squared } \\
Adj R-squared & 0,7679 & F-statistic & 13,2090 \\
\hline
\end{tabular}

Terjadinya konvergensi absolut pada UMK dapat dilihat dari koefisien regresi lag UMK. Koefisien regresi dari lag UMK bernilai negatif dan signifikan menunjukkan kecenderungan terjadinya konvergensi pada tingkat awal UMK di Pulau Jawa periode 2014-2018. Kecepatan konvergensi UMK sebesar 18,5 persen tiap tahunnya dan paruh waktu untuk menutup kesenjangan adalah 3 hingga 4 tahun. Pada analisis konvergensi absolut, perekonomian diasumsikan tidak memiliki perbedaan karakteristik pada setiap daerah. Terjadinya konvergensi absolut dapat diartikan bahwa daerah dengan UMK yang rendah memiliki pertumbuhan yang lebih cepat daripada daerah dengan UMK yang tinggi, sehingga ketimpangan dapat berkurang. Pada analisis konvergensi absolut, variabel yang digunakan terbatas. sehingga konvergensi perlu dilanjutkan dengan menambah variabel lain sebagai kontrol.

\section{Analisis Konvergensi Beta Kondisional}

Konvergensi beta kondisional menggunakan Geographically Weighted Panel Regression (GWRPanel). Langkah awal dalam GWR-Panel adalah melakukan permodelan fixed effect model (FEM) sebagai regresi global dengan asumsi bahwa setiap unit pengamatan memiliki karakteristik yang berbeda. Hasil uji Chow dan Hausman menunjukkan nilai p-value kurang dari tingkat signifikansi 0,05. Berdasarkan uji Chow dan uji Hausman maka diperoleh kesimpulan bahwa fixed effect model adalah model yang terbaik.

Tabel 2. Konvergensi beta kondisional UMK di Pulau Jawa dengan regresi global.

\begin{tabular}{|c|c|c|c|c|}
\hline Variabel & Koefisien & Std Error & t-stat & P-value \\
\hline InUMK $K_{i, t-1}$ & $-0,3631$ & 0,0241 & $-15,0766$ & 0,0000 \\
\hline InPDRB ${ }_{i t}$ & 0,4799 & 0,0541 & 8,8600 & 0,0000 \\
\hline InTKK & $-0,0771$ & 0,1609 & $-0,4787$ & 0,6324 \\
\hline InPAD it & $-0,0017$ & 0,0096 & $-0,1744$ & 0,8616 \\
\hline$\lambda$ & 0,4511 & & & \\
\hline
\end{tabular}




\begin{tabular}{lccc} 
Half-life & 1,53 & & \\
\hline & & Ringkasan Statistik & 146,691 \\
R-squared & 0,5542 & F-statistic & 0,0000 \\
Adj R-squared & 0,4389 & P-value &
\end{tabular}

Konvergensi beta kondisional mempertimbangkan variabel lain yang dapat dikontrol sehingga memicu terjadinya konvergensi. Hasil estimasi pada tabel 2 menunjukkan bahwa nilai koefisien variabel lag dari UMK sebesar -0,3631. Nilai koefisien variabel lag yang negatif dan signifikan menunjukkan terjadinya konvergensi kondisional. Kecepatan konvergensi UMK di Pulau jawa sebesar 45,11 persen tiap tahun berdasarkan nilai implied $\lambda$. Half-life convergence bernilai 1,53 sehingga waktu untuk menutup separuh ketimpangan UMK adalah satu hingga dua tahun.

Asumsi klasik yang harus terpenuhi jika menggunakan model regresi data panel adalah asumsi normalitas, non-multikolinearitas, nSon-autokorelasi, dan homoskedastisitas. Hasil permodelan dengan fixed effect model menunjukkan bahwa asumsi normalitas dan autokorelasi telah terpenuhi dengan nilai $p$-value pengujian kurang dari 0,05 . Seluruh nilai VIF dari variabel dependen yang digunakan bernilai kurang dari 5 sehingga tidak ada korelasi antar variabel dependen yang dipakai. Uji homoskedastisitas dilakukan dengan uji Breusch-Pagan. Hasil pengujian menunjukkan nilai $p$-value kurang dari tingkat signifikansi sebesar 0,05 . Hal ini berarti terjadi heteroskedastisitas pada model yang dihasilkan. Terjadinya heteroskedastisitas diartikan bahwa terdapat keragaman varians antar pengamatan. Untuk mengatasi terlanggarnya asumsi homoskedastisitas maka dibuat permodelan dengan mempertimbangkan aspek spasial keragaman antar wilayah menggunakan Geographically Weighted Panel Regression (GWR-Panel).

Sebelum mengestimasi model GWR-Panel, melakukan transformasi data sesuai dengan within estimator pada FEM. Untuk menguji aspek spasial yaitu heterogenitas pada data transformasi dilakukan uji Breusch-Pagan. Hasil uji Breusch-Pagan pada data transformasi menunjukkan nilai pvalue kurang dari tingkat signifikansi sebesar 0,05. Hal ini berarti minimal terdapat satu varians yang tidak sama di antara wilayah yang diamati

Tabel 3. Penentuan Bandwidth optimum fungsi penimbang GWR-Panel.

\begin{tabular}{cccc}
\hline Fungsi Pembobot Kernel & Bandwidth & Nilai CV & AIC \\
\hline Bisquare & 189 & 0,5234 & $-2233,118$ \\
Gaussian & 33 & 0,5130 & $-2531,962$ \\
\hline
\end{tabular}

Langkah awal dalam permodelan GWR-Panel adalah menentukan penimbang spasial. Penimbang yang dipakai antara lain Bisquare dan Gaussian. Kriteria AICc dan CV dipakai untuk menentukan bandwith optimum pada masing-masing penimbang. Dari hasil pengolahan diperoleh bandwidth optimum pada penimbang Gaussian karena menghasilkan nilai CV dan AICc terkecil.

Tabel 4. Konvergensi beta kondisional UMK di Pulau Jawa dengan GWR-Panel.

Variabel Koefisien GWR-Panel

\begin{tabular}{cccccc}
\cline { 2 - 5 } & Minimum & Kuartil Bawah & Median & Kuartil Atas & Maksimum \\
\hline InUMK $_{\mathrm{i}, \mathrm{t}-1}$ & $-0,6429$ & $-0,4599$ & $-0,3744$ & $-0,3129$ & $-0,1060$ \\
InPDRB $_{\text {it }}$ & 0,0894 & 0,2821 & 0,4982 & 0,7156 & 1,2254 \\
InTKK $_{\text {it }}$ & $-1,2596$ & $-0,1149$ & 0,1818 & 0,4412 & 0,9898 \\
InPAD it & $-0,0607$ & $-0,0126$ & $-0,0068$ & 0,0089 & 1,2254 \\
Konstanta & $-0,0102$ & $-0,0069$ & $-0,0058$ & $-0,0047$ & $-0,0018$ \\
\hline
\end{tabular}

Nilai koefisien lag UMK berada di antara $-0,6429$ dan $-0,1060$. Tanda negatif pada lag UMK berarti bahwa terjadi konvergensi upah minimum di Pulau Jawa pada periode 2014-2018. Terjadinya konvergensi pada upah minimum sejalan dengan penelitian yang dilakukan oleh Arishaldi (2018) dimana terjadi konvergensi upah minimum di Pulau Kalimantan. Moazzami (1997) meneliti konvergensi upah regional pada 10 provinsi di Kanada mendapatkan hasil bahwa terjadi konvergensi upah per pekerja pada daerah yang diteliti. Hal ini berbeda dengan Wahyuni (2011) dimana tidak terjadi konvergensi di Pulau Jawa dengan pendekatan PDRB akan tetapi terjadi 
konvergensi dengan pendekatan pengeluaran rumah tangga. Yudistira (2019) menggunakan metode panel dinamis spasial menemukan bahwa terjadi konvergensi PDRB di Pulau Jawa.

Kecepatan konvergensi pada setiap daerah bervariasi. Daerah dengan kecepatan konvergensi UMK tinggi cenderung berkelompok pada kabupaten/kota di Provinsi Jawa Tengah. Sebagai contoh adalah Kabupaten Purbalingga, Kabupaten Banjarnegara, dan Kabupaten Klaten yang memiliki kecepatan konvergensi lebih dari 63 persen sehingga membutuhkan waktu 1 tahun untuk mencapai paruh waktu konvergensi. Daerah dengan kecepatan konvergensi yang rendah juga terlihat berkelompok. Daerah di perbatasan Provinsi Jawa Timur dan Jawa Tengah sebagai contoh adalah Kabupaten Ngawi, Kabupaten Blora, dan Kabupaten Magetan memiliki kecepatan konvergensi kurang dari 36 persen tiap tahun sehingga membutuhkan waktu 2-3 tahun untuk mencapai separuh konvergensi. Kecepatan konvergensi yang rendah juga terjadi pada kota dalam Provinsi DKI Jakarta dan daerah di sekitarnya sebagai contoh Kota Depok, Kota Tangerang dan Kota Tangerang Selatan yang membutuhkan waktu 4-6 tahun untuk mencapai paruh waktu konvergensi.

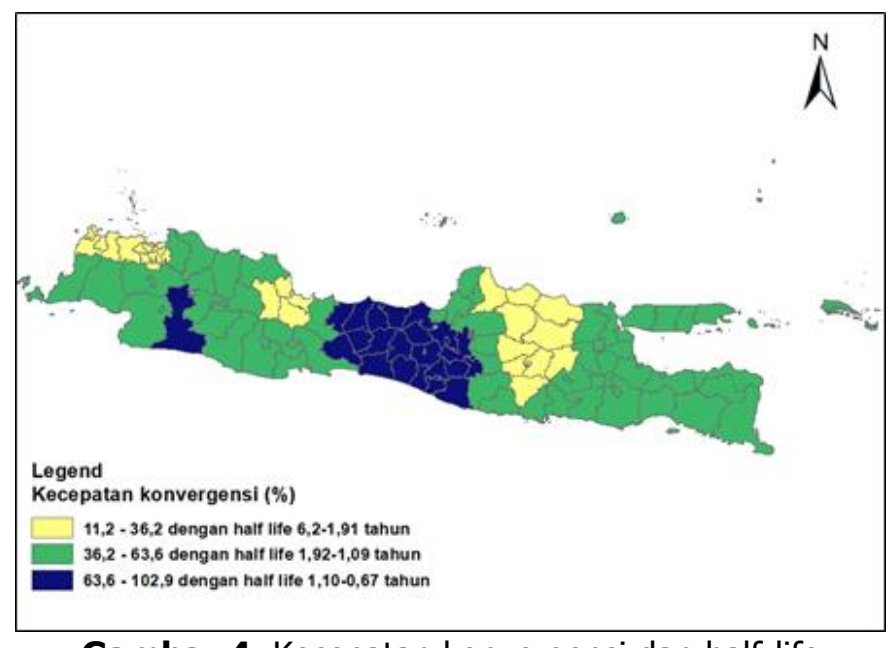

Gambar 4. Kecepatan konvergensi dan half-life

Suatu wilayah dikatakan mencapai konvergensi jika koefisien dari variabel lag bernilai negatif dan signifikan. Terdapat beberapa daerah dengan koefisien lag yang tidak signifikan, sehingga tidak semua kabupaten/kota di Pulau Jawa mencapai konvergensi. Dari 119 kabupaten dan kota di Pulau Jawa, daerah yang dapat mencapai konvergensi sebanyak 68 daerah. Rata-rata UMK pada daerah yang mencapai konvergensi adalah Rp. 2.009.568 pada tahun 2018. Daerah yang mencapai konvergensi merupakan daerah dengan UMK yang rendah terlepas dari Kabupaten Bekasi, Kota Surabaya, Kabupaten Gresik, Kabupaten Sidoarjo, Kabupaten Pasuruan, Kabupaten Mojokerto, dan Kabupaten Purwakarta yang menetapkan UMK di atas Rp. 3.000.000 pada tahun 2018. Kabupaten/kota yang mencapai konvergensi ditampilkan pada gambar 5 .

Untuk mengetahui apakah model GWR-Panel lebih baik dibandingkan model global maka dilakukan uji goodness of fit. Pada hasil pengujian menunjukkan bahwa nilai $\mathrm{F}^{*}$ sebesar 0,6759. Nilai $\mathrm{F}^{*}$ kurang dari nilai $\mathrm{F}$ tabel sehingga keputusan yang diambil adalah menolak $\mathrm{H}_{0}$. Dari pengujian dapat disimpulkan bahwa pada tingkat signifikansi 0,05 model GWPR lebih baik dibandingkan model global. Hal ini berarti besarnya pengaruh pada masing-masing variabel independen berbeda pada setiap wilayah.

Tabel 5. Analisis varians

\begin{tabular}{llllll}
\hline Model & SS & df & MS & F & P-value \\
\hline GWR error & 0.4084 & 524.87 & 0.0007 & 0.6759 & 0,0000 \\
Global error & 0.5434 & 472 & 0.0011 & & \\
\hline
\end{tabular}

Untuk mengetahui koefisien regresi yang signifikan pada setiap kabupaten/kota dilakukan pengujian parsial pada setiap koefisien lokal pada tingkat signifikansi 0,05. Variabel lag UMK signifikan pada 68 kabupaten/kota di Pulau Jawa, sehingga terdapat kabupaten/kota yang konvergen dan tidak konvergen. Daerah yang konvergen adalah daerah dengan koefisien Lag UMK 
bernilai negatif dan signifikan. Variabel PDRB berpengaruh terhadap konvergensi UMK pada 44 kabupaten/kota di Pulau Jawa, variabel TKK berpengaruh pada 14 kabupaten/kota, dan variabel PAD berpengaruh pada 4 kabupaten/kota di Pulau Jawa.

Model GWR-Panel yang dihasilkan berbeda pada setiap wilayah. Model yang terbentuk bergantung pada nilai koefisien regresi dan variabel dependen yang signifikan mempengaruhi konvergensi UMK di Pulau Jawa. Perbedaan signifikansi variabel pada masing-masing wilayah memungkinkan untuk dilakukannya pengelompokan kabupaten/kota berdasarkan variabel yang signifikan.

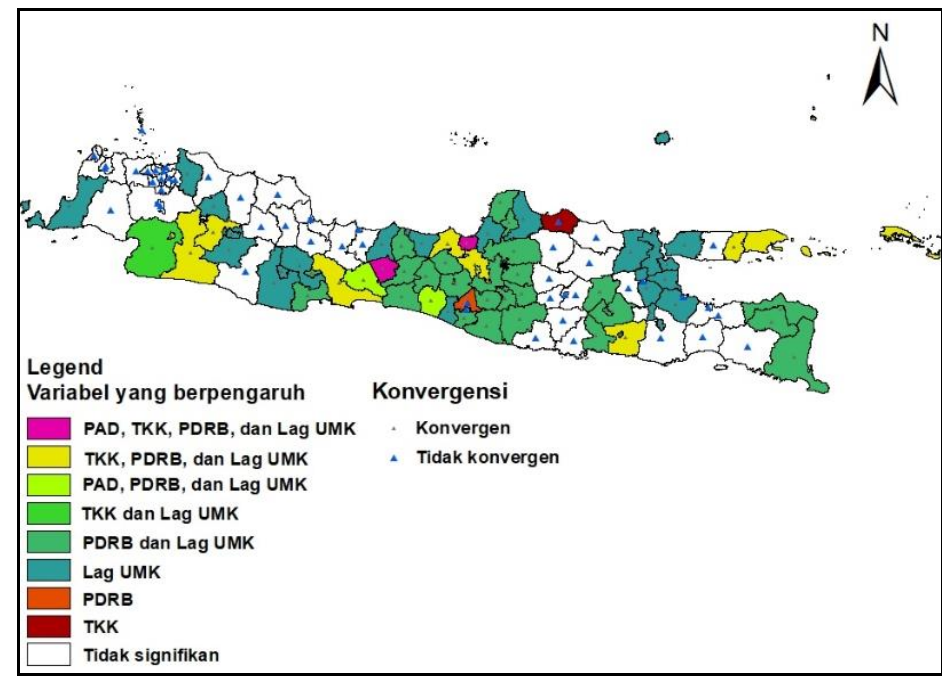

Gambar 5. Peta pengelompokan kabupaten/kota berdasarkan konvergensi dan variabel yang memengaruhi pertumbuhan UMK

Model yang dihasilkan pada pemodelan GWR-Panel berbeda pada setiap kabupaten/kota. Dengan pemodelan GWR-Panel terdapat 119 persamaan untuk mengetahui variabel yang berpengaruh signifikan terhadap konvergensi UMK di Pulau Jawa. Sebagai contoh adalah persamaan regresi dengan i adalah Kabupaten Pamekasan dan Kabupaten Rembang, maka persamaan regresinya adalah sebagai berikut.

$$
\begin{aligned}
& \text { In } \widehat{U M K}_{\text {Pamekasan,t }}=-0,0048-0,3336 \text { lnUMK }{ }_{\text {Pamekasan,t-1 }}-0,0517 \text { lnTKK }{ }_{\text {Pamekasan,t }}+ \\
& 0,0227 \text { lnPAD } \text { Pamekasan,t }+0,3721 \text { lnPDRB }_{\text {Pamekasan,t }}
\end{aligned}
$$

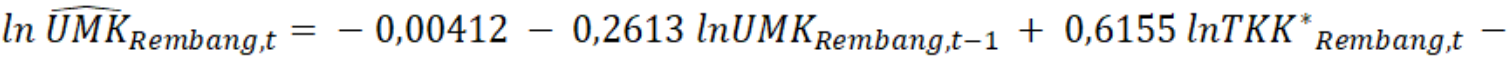
$0,0044 \ln P A D_{\text {Rembang,t }}$

$+0,2514 \ln P D R B_{\text {Rembang,t }}$

*) signifikan pada tingkat signifikansi 0,05

Laju konvergensi $(\lambda)$ yang terjadi adalah sebagai berikut:

$\lambda_{\text {Pamekasan }}=-\ln (1-0,3336)$.

$\lambda_{\text {Pamekasan }}=0,4059$

Waktu paruh ( Half-life) yaitu:

$\tau_{\text {Pamekasan }}=\frac{\ln (2)}{\lambda_{\text {Pamekasan }}}$

$\tau_{\text {Pamekasan }}=1,707$

Dari model di atas diketahui bahwa Kabupaten Pamekasan akan mencapai konvergensi dengan kecepatan sebesar 40,59 persen setiap tahunnya dan membutuhkan 1-2 tahun untuk menutup separuh kesenjangan. Sedangkan Kabupaten Rembang diperoleh hasil koefisien lag dari 
UMK bernilai negatif yaitu $-0,2613$ dan tidak signifikan. Dapat diartikan bahwa Kabupaten Rembang tidak mencapai konvergensi UMK. Variabel yang mempengaruhi pertumbuhan UMK di Kabupaten Pamekasan adalah lag UMK, PDRB dan TKK. Pada Kabupaten Rembang, hanya variabel TKK yang mempengaruhi pertumbuhan UMK. Variabel TKK berpengaruh pada Kabupaten Pamekasan dan Kabupaten Rembang akan tetapi memiliki arah koefisien yang berbeda. Peningkatan satu persen TKK di Kabupaten Pamekasan menurunkan pertumbuhan UMK sebesar 0,052 persen sedangkan pada Kabupaten Rembang justru akan meningkatkan pertumbuhan UMK yaitu 0,616 persen dengan asumsi variabel lain konstan. Hal ini disebabkan kondisi ketenagakerjaan di Kabupaten Rembang. Jika dilihat dari ketenagakerjaan di Kabupaten Rembang, TKK mengalami peningkatan sebesar 0,32 persen dari tahun 2017 ke tahun 2018. Meskipun TKK mengalami peningkatan, jumlah penduduk yang bekerja mengalami penurunan sebesar 0,33 persen yang berarti bahwa peningkatan TKK ini diakibatkan penurunan jumlah angkatan kerja yang besar. Pekerja informal mendominasi dengan persentase sebesar 60,63 persen pada tahun 2018, sedangkan regulasi UMK tidak mencakup pekerja informal.

\section{KESIMPULAN}

Selama tahun 2014-2018 rata-rata UMK, TKK, dan PDRB di Pulau Jawa mengalami peningkatan setiap tahun, kecuali PAD mengalami penurunan pada tahun 2018. Berdasarkan pembagian dalam peta tematik ditemukan bahwa terdapat indikasi hubungan antara TKK, PAD, dan PDRB dengan UMK. Konvergensi absolut terjadi pada UMK di Pulau Jawa yang menunjukkan bahwa UMK yang ditetapkan pemerintah tanpa mengontrol variabel lain dapat memicu terjadinya konvergensi. Pulau Jawa mengalami konvergensi sigma dan konvergensi absolut maupun kondisional pada periode waktu penelitian. Kecepatan konvergensi absolut di Pulau Jawa pada regresi global sebesar 18,5 persen sehingga membutuhkan waktu 3-4 tahun untuk menutup separuh kesenjangan UMK. Dari hasil GWR-Panel 68 daerah di Pulau Jawa mencapai konvergensi dengan kecepatan antara 32\% hingga 103\% sedangkan 51 daerah lainnya tidak mencapai konvergensi. Pengaruh variabel PAD, TKK, dan PDRB terhadap pertumbuhan UMK berbeda pada setiap kabupaten/kota di Pulau Jawa. Pengaruh tertinggi pada PAD dan PDRB terdapat pada Kabupaten Purbalingga sedangkan TKK pada Kabupaten Cianjur. Sebagian besar PAD dan PDRB berpengaruh positif dan TKK berpengaruh negatif terhadap pertumbuhan UMK pada daerah yang signifikan.

\section{DAFTAR PUSTAKA}

Arishaldi G. (2018). Konvergensi Upah Provinsi di Pulau Kalimantan [Skripsi]. Bogor: Institut Pertanian Bogor.

Barro, Robert J dan Sala-i-Martin X. (1992). Convergence. Journal of Political Economy 100(2):223-251.

Barro, Robert J dan Sala-i-Martin, X. (2004). Economic Growth. Cambridge: MIT Press.

Bruna, F., \& Yu, D. (2013). Geographically Weighted Panel Regression. XI Congreso Galego de Estatica e Investigacion de Operations. A Coruna.

Baumol, W.J. (1986). Productivity Growth, Convergence, and Welfare: What the Long Run Data Show. American Economic Review, 76 (5), 1072-1085.

Eckey, H, Kosfeld, R; Türck, M. (2005). Regional Convergence in Germany: A Geographically Weighted Regression approach. Volkswirtschaftliche Diskussionsbeiträge, 76(5), 1-27.

Mazza, A \& Villaverde, J. (2006). A Territorial Analysis of Wage Convergence/Differentials in Spain. Revue d'Économie Régionale \& Urbaine. 615-630.

Moazzami. (1997). Regional Wage Convergence in Canada: An Error-Correction Approach. Canadian Journal of Regional Science. 341-350.

Rahayu, N. (2017). Geographically Weighted Panel Regression Untuk Pemodelan

Persentase Penduduk Miskin Di Provinsi Jawa Tengah [Tesis]. Surabaya: Institut Teknologi Sepuluh Nopember.

RI (Republik Indonesia). (2013). Peraturan Menteri Tenaga Kerja dan Transmigrasi No. 7 Tahun 2013 tentang Upah Minimum. Sekretariat Negara. Jakarta.

Simanjuntak, Payaman J. (2002). Pengantar Ekonomi Sumber Daya Manusia. Jakarta: Lembaga Penerbit FEUI.

Todaro, Michael P. (2000). Pembangunan Ekonomi di Dunia Ketiga, Edisi ke tujuh. Jakarta: Erlangga. 
Wahyuni, K. (2011). Konvergensi dan Faktor-faktor yang Memengaruhi Ketimpangan Wilayah Kabupaten/Kota Di Pulau Jawa [Tesis]. Bogor: Institut Pertanian Bogor.

Yu, D. (2010). Exploring Spatiotemporally Varying Regressed Relationships: The Geographically Weighted Panel Regression Analysis. The International Archives of the Photogrammetry, Remote Sensing and Spatial Information Sciences, 38(2), 134-139.

Yudhistira M. (2018). Analisis Konvergensi Ekonomi Kabupaten/Kota Pulau Jawa Tahun 2013-2017 Menggunakan Data Panel Spasial [Skripsi]. Jakarta: Sekolah Tinggi Ilmu Statistik. 